
\title{
CIÊNCIA'NATURA
}

\section{Investigation of the potential sources of water pollution affecting the Companhia Hidromineral Caldas da Imperatriz through physical, chemical, and biological analyses}

Investigação das potenciais fontes poluidoras da água da Companhia Hidromineral Caldas da Imperatriz por análise físico-químico-biológica

Leopoldo Duarte Pereira, Marcielly Melo Freitas, Aline Ferreira Ali de Ávila, José Gabriel da Silva e Rachel Faverzani Magnago

Universidade do Sul de Santa Catarina, Palhoça, Brasil

\section{Resumo}

A água constitui-se em elemento essencial à vida. O acesso à água de boa qualidade e em quantidade adequada está diretamente ligado à saúde da população. Este trabalho tem por objetivo investigar as potenciais fontes poluidoras da água da Companhia Hidromineral Caldas da Imperatriz por análise fisico-químico-biológica na minimização dos riscos à saúde dos usuários. Foram realizadas seis coletas em diferentes meses de 2015. No laboratório foram analisados os parâmetros químicos ( $\mathrm{pH}, O D, D B O$, nitrito, nitrato e sulfato), fisicos (cor, turbidez e temperatura) e biológico (coliformes totais e termotolerantes). Os resultados obtidos foram comparados com os valores máximos permitidos pelas resoluções 357/2005 e 396/2008 do CONAMA e pela portaria 2914/2011 do Ministério da Saúde. Os parâmetros analisados atenderam as legislações vigentes, com exceção da análise de nitrito realizada no dia 02 de março, que sofreu alteração provavelmente devido às chuvas dos dias anteriores, $e$ o DBO para todas as amostras ficaram acima do valor máximo permitido pela resolução 357/2005 do CONAMA. Foi verificado como possivel fonte poluidora para as águas da Companhia Hidromineral Caldas da Imperatriz os efluentes dos hotéis no entorno, visto que não existe outras fontes de poluição antrópica, tais como plantações, passagem de gado e indústrias.

Palavras-chave: Água subterrânea. Parâmetros de Qualidade. Água Termal

\section{Abstract}

Water is an essential element for life. Accessing good quality and adequate water is directly linked to the people's health. The aim of this study was to investigate the potential sources of water pollution affecting the Company Hidromineral Caldas da Imperatriz through physical, chemical, and biological analysis to reduce the risks of health hazards. Laboratory tests encompassed chemical parameters ( $p H, D O, B O D$, nitrite, nitrate, and sulfate), physical parameters (color, turbidity and temperature), and biological parameters (total and thermotolerant coliforms). The results obtained were compared to the maximum values allowed by the CONAMA resolutions 357/2005 and 396/2008, and by Ordinance 2914/2011 of the Ministry of Health. The analyzed parameters met the current legislation, except for the nitrite analysis performed on March 2, which presented alterations probably because of the rainfall during the previous days, and BOD for all samples, which was above the maximum value allowed by the CONAMA resolution 357/2005. Wastewaters from nearby hotels were the possible source of pollution affecting the waters of the Companhia Hidromineral Caldas da Imperatriz, since there were no other sources of anthropic pollution, such as plantations, livestock, and industries. 


\section{Introduction}

Freshwater is a finite natural resource, whose quality has been worsening due to the growth of population, and the absence of public policies aimed at its preservation (MERTEN; MINELLA, 2002). Water is an essential element in life. Access to good quality, adequate water is directly linked to the population's health, and this fundamental human right is being threatened (JOHNSON, 2016; UNITED NATIONS, 2013; REBOUÇAS, 1999; IBGE, 2008).

Fresh water for human consumption can come from surface water or groundwater abstraction. Groundwater is used by a large part of the Brazilian population because it provides potable water to the country's urban and rural populations, as well as to remedy the lack of a water supply system, reduce costs, and avoid water privatization (JOHNSON, 2016; ROYAL, 2005). The volume of groundwater abstraction is increasing progressively, as it also meets the demands of industries, irrigation, and tourism. Despite its contribution to the socioeconomic development of several regions of the country, groundwater management is still incipient and does not reflect its current and strategic importance. The lack of knowledge of the risks of anthropic contamination affecting water quality is worrisome (HIRATA, 2016; LAZZERINI, 2013). Groundwater lies at different depths and deeper springs usually protected by a rock layer are known as confined sheets, with little possibility of contamination, although more difficult to abstract. Water sources close to the surface are known as free aquifers, which are easy to abstract; however, water can be easily contaminated (SILVA; ARAUJO, 2003). Several factors influence water quality of a watershed, such as rainfall, vegetation cover, topography, geology, as well as the type, use, and management of the soil located in the river basin (MARQUES, 2016; VERONEZ, 2011); UNESCO, 1998). Contamination of the underground springs is due to a series of factors related to the disorderly growth of the cities, inadequate disposition of residues, lack of sanitary sewage systems, and the lack of urban planning (MENEZES, 2014; LAZZERINI, 2013; LOBLER, 2013; CUNHA; SHIRAIWA, 2011, MERTEN, 2002).

Southern Brazil holds the third largest concentration of hydro-mineral districts, with concessions for mineral water and table potable water withdrawal. Of the 515 productive bottled water plants and beverage manufacturing in 2015 Brazil, 13 were from the state of Santa Catarina (DNPM, 2016; VAITSMAN; VAITSMAN, 2005). Among them, Caldas da Imperatriz also provides thermal baths in local hotels and in a bathhouse, which is a paid public thermal establishment, as well as potable water for free to local people, while visitors have to pay (QUINTELA, 2003; SILVA; MELLO, 2002; NOTÍCIAS DO DIA, 2017). The city was home to 19,823 people in 2010 , according to the IBGE, with an estimated 21,920 population for the year 2015. According to the city Secretary of Tourism (2014), the economy is divided into two major sectors, agriculture and tourism. Tourism is the most important economic activity for the municipality, with its hotel network having the hydro-mineral resources linked to cultural and historical facts (SEWELL, 2011).

According to the Ministry of Health (2011), "water for human consumption is water that meets the drinking standards established in this Ordinance, and that does not pose risks to health, suitable for drinking, preparation, and production of food and personal hygiene, regardless of its origin".

The aim of this study was to examine the major chemical, physical and biological parameters, during a 6-month sampling campaign, of the thermal spring water run by the Companhia Hidromineral Caldas da Imperatriz, located in Caldas da Imperatriz, state of Santa Catarina, Brazil. The study was also intended to relate water quality with rainfalls in the region to reduce risks to users.

\section{Methodology}

We examined the study area characteristics, carried out physicochemical and biological analyses of water samples of the Companhia Hidromineral Caldas da Imperatriz, and checked the rainfall amounts and estimated precipitation in the region during the sampling period.

\subsection{Study Area Characterization}

Visits were made to the thermal spring on February 2, March 6, April 4, August 12, September 8, and October 5, 2015. The surroundings of the Companhia Hidromineral Caldas da Imperatriz were also examined.

\subsection{Rainfall information}

Rainfall data and images were retrieved from the website of the Center for Weather Forecasting and Climate Studies (Centro de Previsão de Tempo e Estudos Climáticos - CPTEC) of the National Institute for Space Research (Instituto Nacional de Pesquisas Espaciais - INPE). 


\subsection{Water Collection and Quality Parameters}

Water samples were collected at a point determined by $27^{\circ} 43^{\prime} 49.9^{\prime \prime}$ latitude and $48^{\circ} 48^{\prime} 37.4^{\prime \prime}$ longitude. At this point, six collections were made on the following dates: February 2, March 6, April 4, August 12, September 8, and October 5, 2015.

Following strict antisepsis procedures, the water samples were collected and transferred to a properly washed flask, and autoclaved for microbiological analysis.

The flasks containing the samples were sealed, identified and conditioned in thermal boxes, which allowed temperature control, and then sent to the laboratory for physicochemical analyses. The analyses were performed in triplicate, and the mean values were calculated.

The results obtained were compared with the CONAMA resolution 357, as of 2005, CONAMA resolution 396, as of 2008, and with the ordinance of the Ministry of Health $n^{\circ} 2914$, as of 2011. We adopted the most restrictive value of the legislation in each case.

\subsubsection{Physical Parameters}

The physical parameters, such as color, turbidity, and temperature were analyzed according to the approach by Laurenti in his book on water quality (LAURENTI, 1997).

\subsubsection{Color}

The HACH color disc test kit was used to determine the color of water.

\subsubsection{Turbidity}

Turbidity reading was performed on the ALFAKIT PLUS Turbidimeter model AT K2, on a scale ranging from 0 to 1000 NTU.

\subsubsection{Temperature}

The temperature was checked by a HANNA HI2484 digital thermometer in situ.

\subsubsection{Chemical Parameters}

Chemical parameters, such as $\mathrm{pH}$, nitrite, nitrate, sulfate, dissolved oxygen, and biochemical oxygen demand were analyzed according to the Practical Handbook of water analysis (FUNASA, 2013).

\subsubsection{1 $\mathrm{pH}$}

The HANNA pH meter model HI 8424 was used to record the $\mathrm{pH}$.

\subsubsection{Nitrite, Nitrate and Sulphate}

The HACH colorimeter model DR/890 was used for nitrite, nitrate, and sulphate determination by using the dissociation method.

\subsubsection{Dissolved oxygen}

An ALFAKIT, AT 130 model Oximeter was used to determine Dissolved Oxygen (DO).

\subsubsection{Biochemical oxygen demand}

A VELP Scientific sensor was used to determine the Biochemical Oxygen Demand (BOD).

\subsubsection{Total and Thermotolerant Coliforms}

Biological parameters were determined by the most probable number (MPN) of total and thermotolerant coliforms according to the Standard Methods for the Examination of Water and Wastewater (APHA, 1998).

The fermentation technique in multiple tubes was used to determine of the MPN of total coliforms and thermotolerant 
coliforms. All the results related to total and thermotolerant coliforms were obtained by using the reference frame for the most probable number as displayed in Table-1 of the Standard Methods for the Examination of Water and Wastewater (APHA, 1998).

\section{Results}

\subsection{Study Area Characterization}

The Companhia Hidromineral Caldas da Imperatriz is located in the municipality of Santo Amaro da Imperatriz, district of Caldas da Imperatriz, state of Santa Catarina, between the equatorial and Capricorn parallels, $27^{\circ} 43^{\prime} 49.9^{\prime \prime} \mathrm{S}$ and 48 48'37.4" W of Greenwich, in the Atlantic coastal area, as shown in Figure 1.

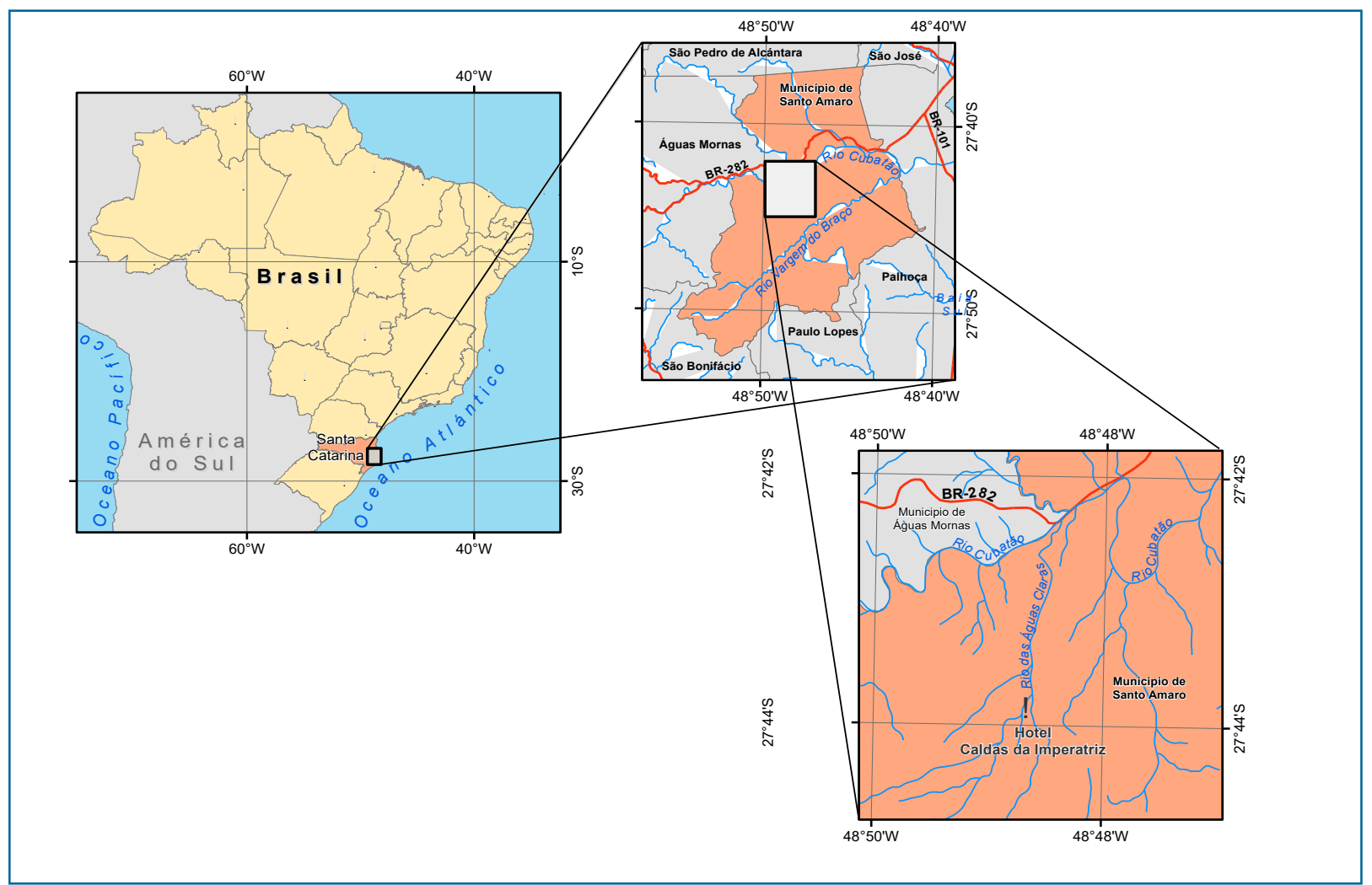

Figure 1 - Location of the municipality of Santo Amaro da Imperatriz, State of Santa Catarina, Brazil Source: The author (2016)

The fountain from where the water samples were collected is located inside the Hotel de Caldas da Imperatriz (Figure 2). The hotel is currently managed by the city hall and is part of the Serra do Tabuleiro State Park.

Figure 3 shows the access to the fountain (right door) and the pump (bottom door) that distributes water for the hotel use and baths.

Figure 4 shows the room where the fountain is located.

The room where the water fountain is located has ultraviolet lights that are kept on to ensure an environment without risks of biological water contamination.

The evaluation of the surroundings of the mineral water fountain was divided into vegetation and topography.

\subsubsection{Vegetation}

The water fountain was located in the satellite image and is shown in Figures 5A and 5B highlighted by a red circle. The surroundings can be observed for the years 2003 and 2014, respectively.

A comparison of the two images reveals the similarity of the vegetation cover between 2003 and 2014. After eleven years of the satellite image in Figure 5A (2003) and in Figure 5B (2014), there was no vegetation cover removal that could be perceived by using the spectral radiation band of the visible region. 


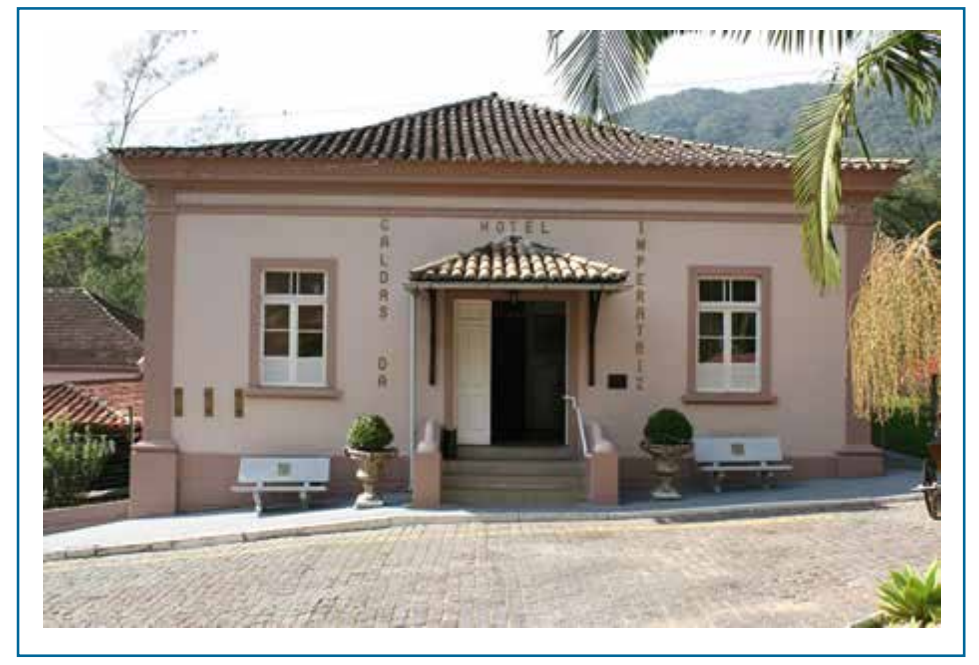

Figure 2 - Hotel of Caldas da Imperatriz where the water fountain is located Source: The author (2016)

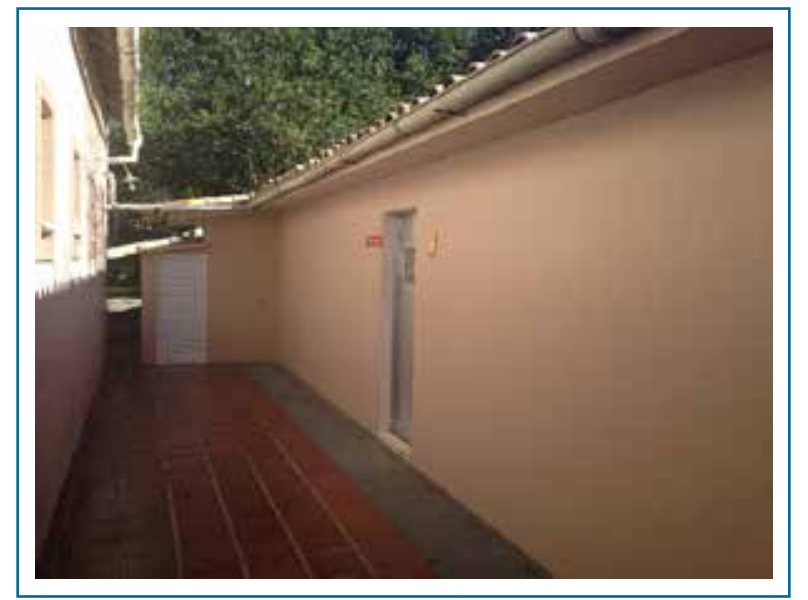

Figure 3 - Image of the outside of the water fountain Source: The author (2016)

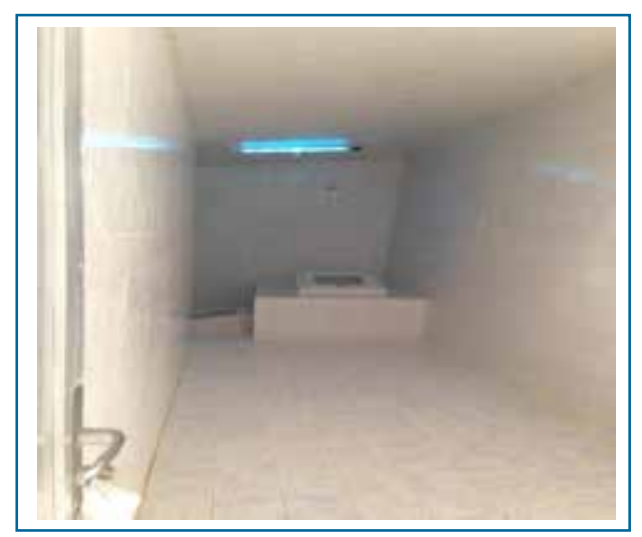

Figure 4 - Image shows the inner part of the water fountain Source: The author (2016) 


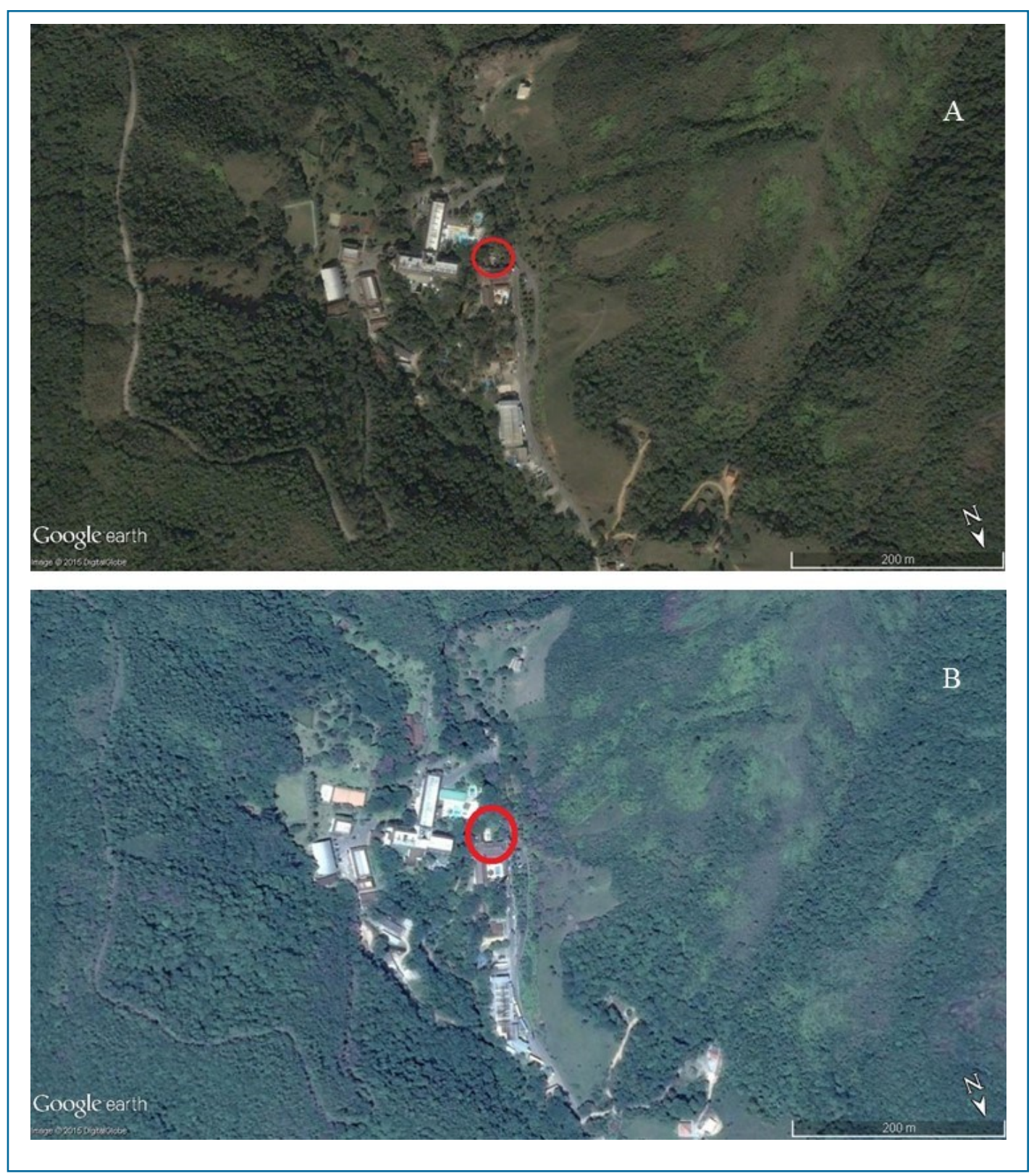

Figure 5 - (A) Satellite image of the fountain site in 2003 and (B) satellite image of the fountain site in 2014 in the municipality of Santo Amaro da Imperatriz

Maintenance and even the possible increase of trees and vegetation surrounding the fountain area was due to several factors, such as increased environmental inspection, environmental awareness, and recognition by the hotels in the area that preservation of the fountain is vital for the tourism industry. Maintaining the vegetal cover contributes to the protection of the fountain and, consequently, the quality of its water.

Soil cover improves the physical and biological properties of the soil, as it results in an increase in soil organic matter, which in turn leads to reduced compaction, as well as increased porosity and soil stability (ROSADO et al., 2012).

Figure 5B also shows there are no residences in the surroundings of the fountain, except for the hotels, which have adequate sewage treatment, posing no risks to water contamination.

\subsubsection{Topography}

Topography is of great importance in terms of water quality, due to the direction and volume of water flow in the studied region. In the satellite image (Figure 6), the fountain is highlighted in yellow, and the topography of the environment refers to the year 2015 . 


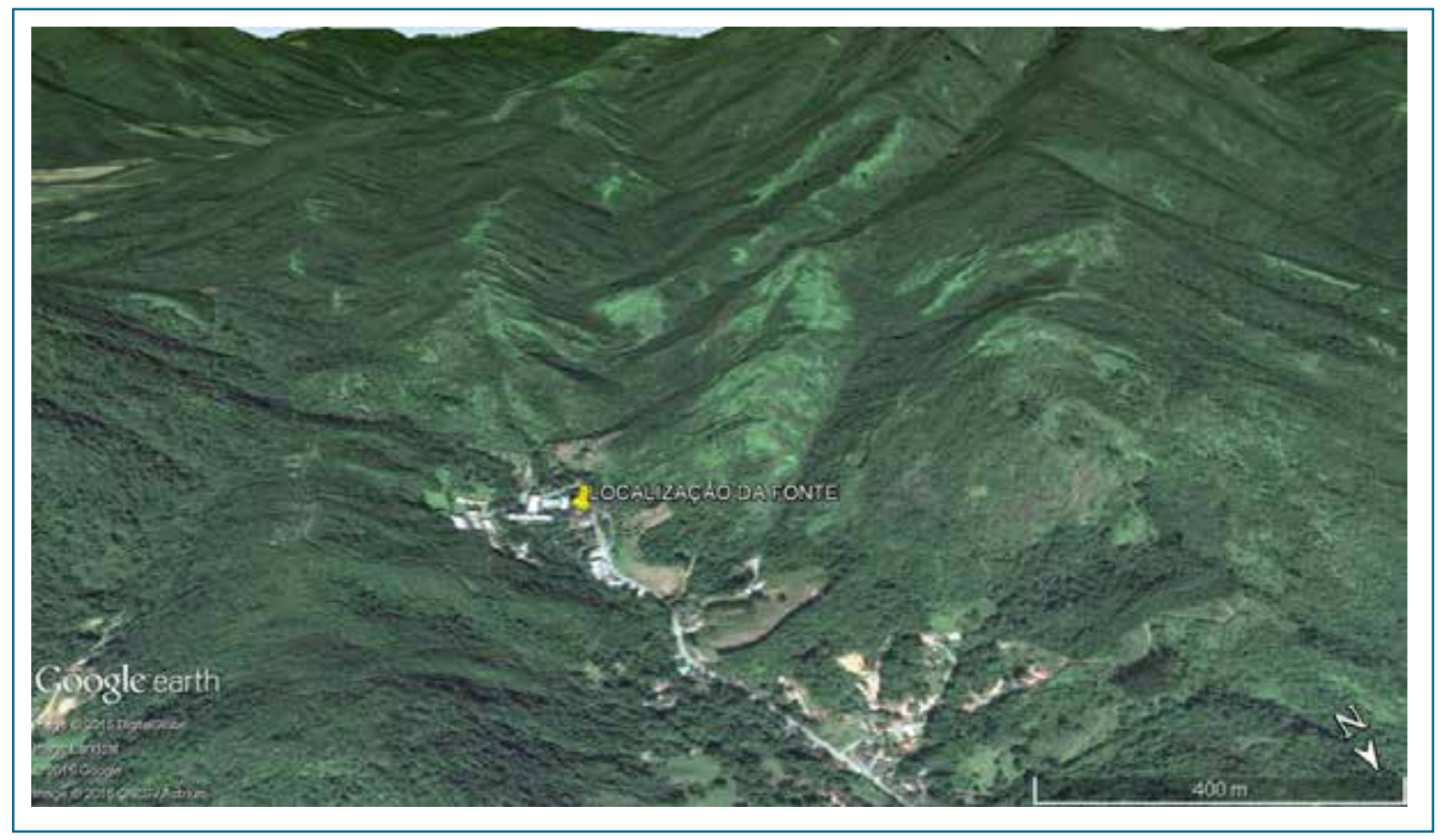

Figure 6 - Topography of the region surrounding the fountain in the municipality of Santo Amaro da Imperatriz

As it can be seen in Figure 6, the fountain is located at the base of a mountain range. In this way, surface water runoff from rainfall will flow towards the fountain. When the amount of rainfall is higher than normal, attention should be paid, given that a large volume of water coming from the surface and subsurface runoff of the mountains may affect water quality. To collect water samples, we took two days into account for the water runoff to reach the fountain.

It should be highlighted that the region is located in the Águas Mornas granite-gneiss complex, belonging to the hydrostratigraphic unit, crystalline basement, which is composed of a great diversity of igneous and metamorphic rocks that are related to a series of pre-Cambrian events. (MACHADO, 2013).

\subsection{Rainfall}

Groundwater sources close to the surface, as is the case of the fountains located in the Caldas da Imperatriz region, can be easily contaminated due to anthropic and even natural activities. Rainfall runoff can carry soil contaminants to the groundwater and compromise its quality.

The first water sample was collected on March 2, 2015, at 2:30 p.m., when some weather changes occurred, but within climate normality. Figure 7 shows the rainfall map for February 28 and March 1-2, 2015, in which the rainfall totals reached 2.1 to 5 millimeters two days before the sample collection, which corresponds to $2.1-51 / \mathrm{m}^{2}$.

Figure 8 shows the rainfall map for April 4, 5, and 6, 2015. According to CPTEC/INPE (2015), precipitation reached from 5.1 to 20 millimeters on the day of the sample collection, but it did not affect the result since the collection occurred at 2 p.m., before the expected rainfall precipitation.

Water samples were also collected on May 4 and August 12, 2015. Rainfall neither occurred on those dates nor during the two days prior to the sample collection. Figure 9 and Figure 10 display the rainfall map for these dates.

Figure 11 shows the rainfall map for August 4, 7, and 8, 2015. According to INPE (2015), a rainfall volume between 5.1 and $20 \mathrm{~mm}$ occurred August 4, but the water sample was collected at 2 p.m., before the expected rainfall precipitation around 2 p.m.

Another water sample was collected on October 5, 2015, at 2:30 p.m. There was no rainfall on that date nor during the two days prior to the sample collection. Figure 12 shows the precipitation maps for those dates.

\subsection{Water Collection and Quality Parameters}

Six water samples were collected for physicochemical and biological analyses to determine water quality parameters. The analyses examined color, turbidity, temperature, dissolved oxygen, $\mathrm{pH}, \mathrm{BOD}$, nitrite, nitrate, sulfate, total coliforms, and thermotolerant coliforms. The results from these analyses served as indicators of pollution parameters. 


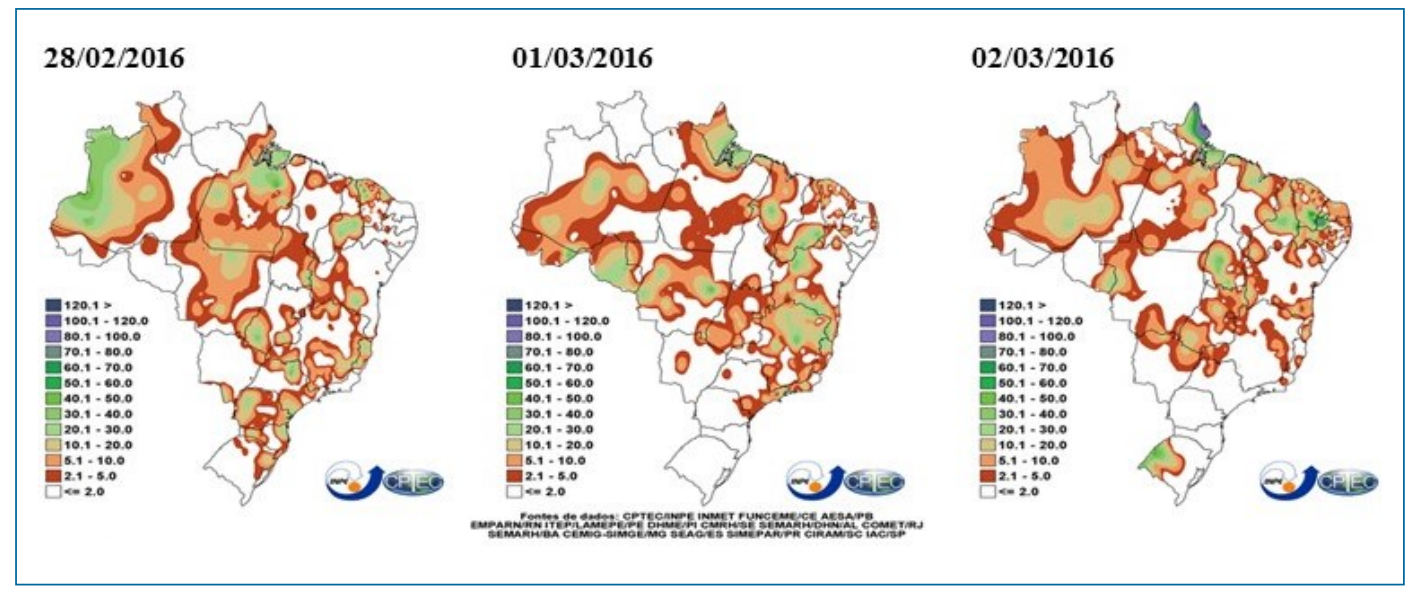

Figure 7 - Rainfall data for February 28 and March 1-2, 2015

Source: Adaptated from (CPTEC/INPE, 2015)

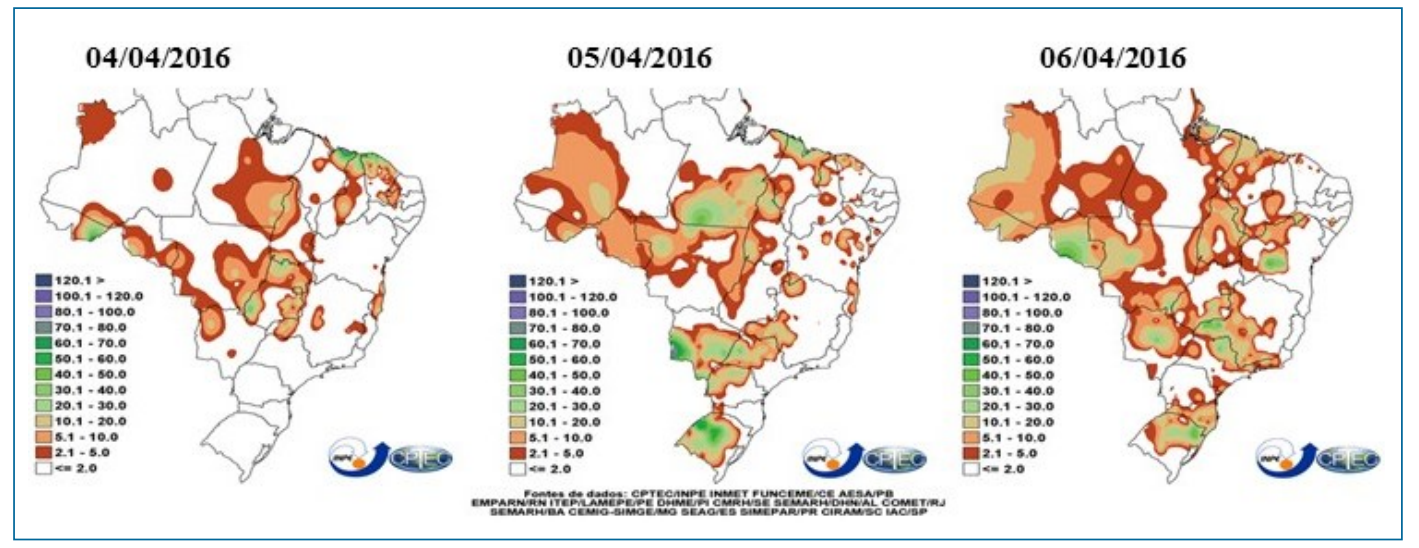

Figure 8 - Precipitation data for April 4, 5, and 6 April, 2015

Source: Adaptated from (CPTEC/INPE, 2015)

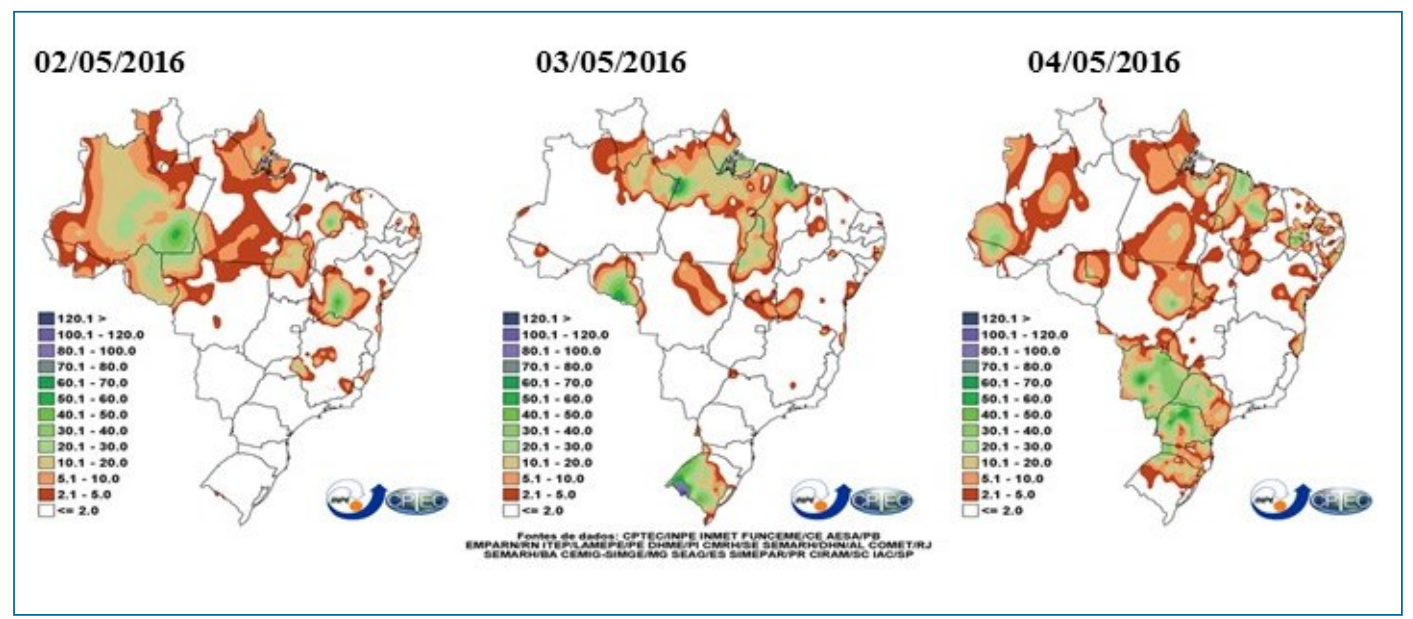

Figure 9 - Rainfall data for May 2, 3, and 4, 2015

Source: Adaptated from (CPTEC/INPE, 2015) 


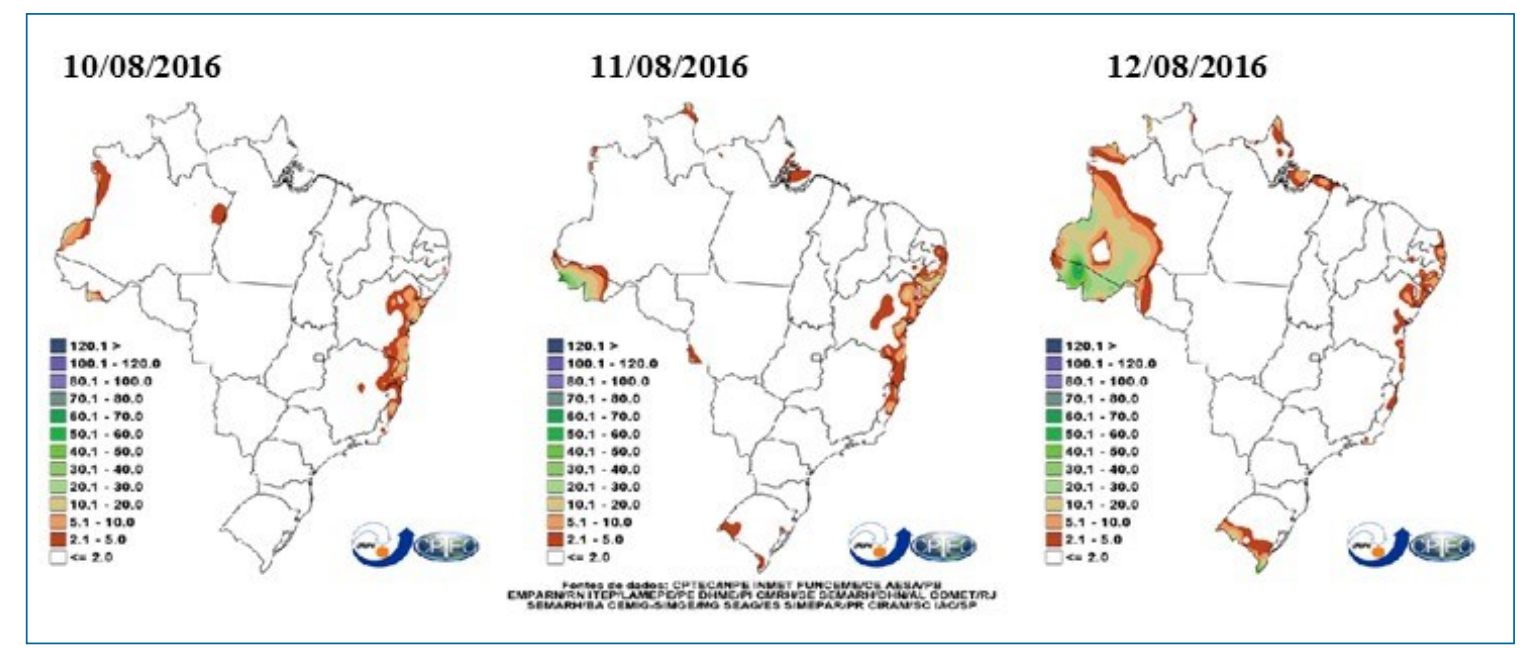

Figure 10 - Rainfall data for August 10, 11, and 12, 2015

Source: Adaptated from (CPTEC/INPE, 2015)

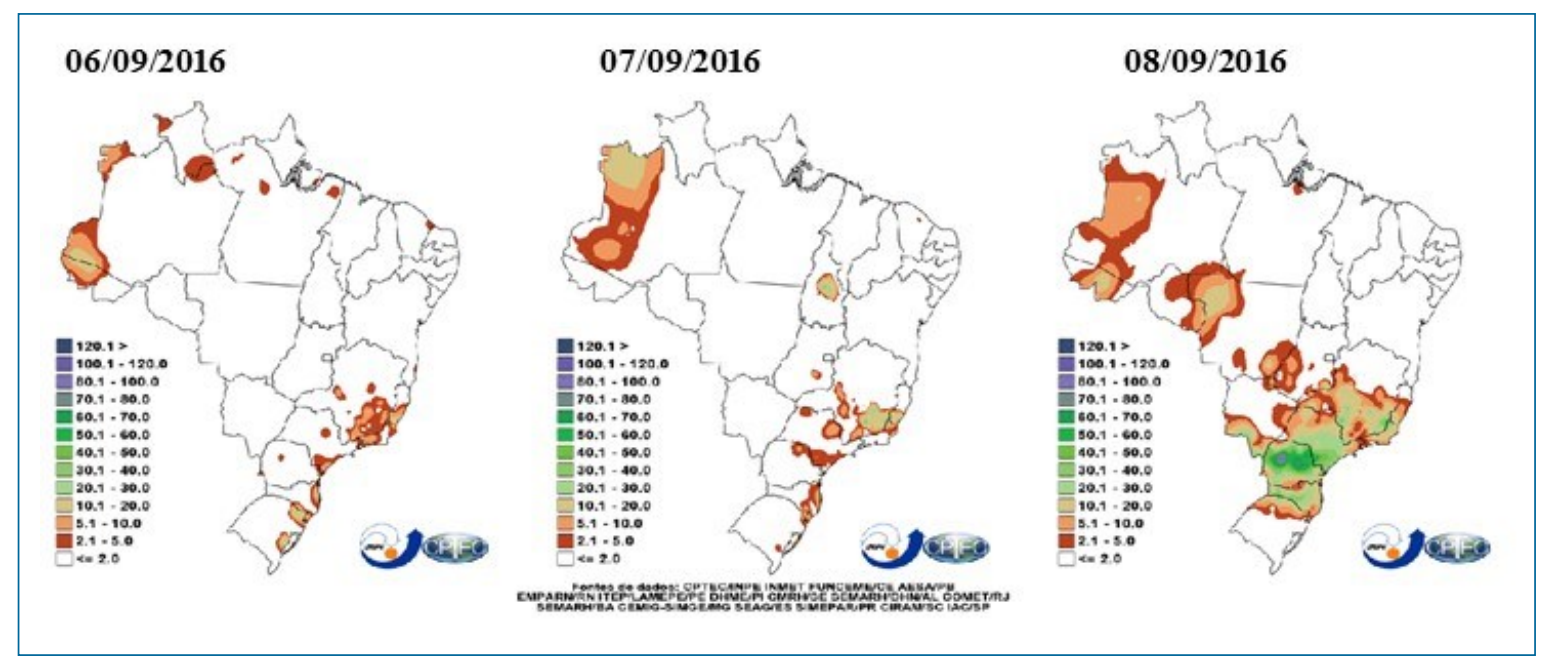

Figure 11 - Rainfall data for September 6, 7, and 8, 2015

Source: Adaptated from (CPTEC/INPE, 2015)

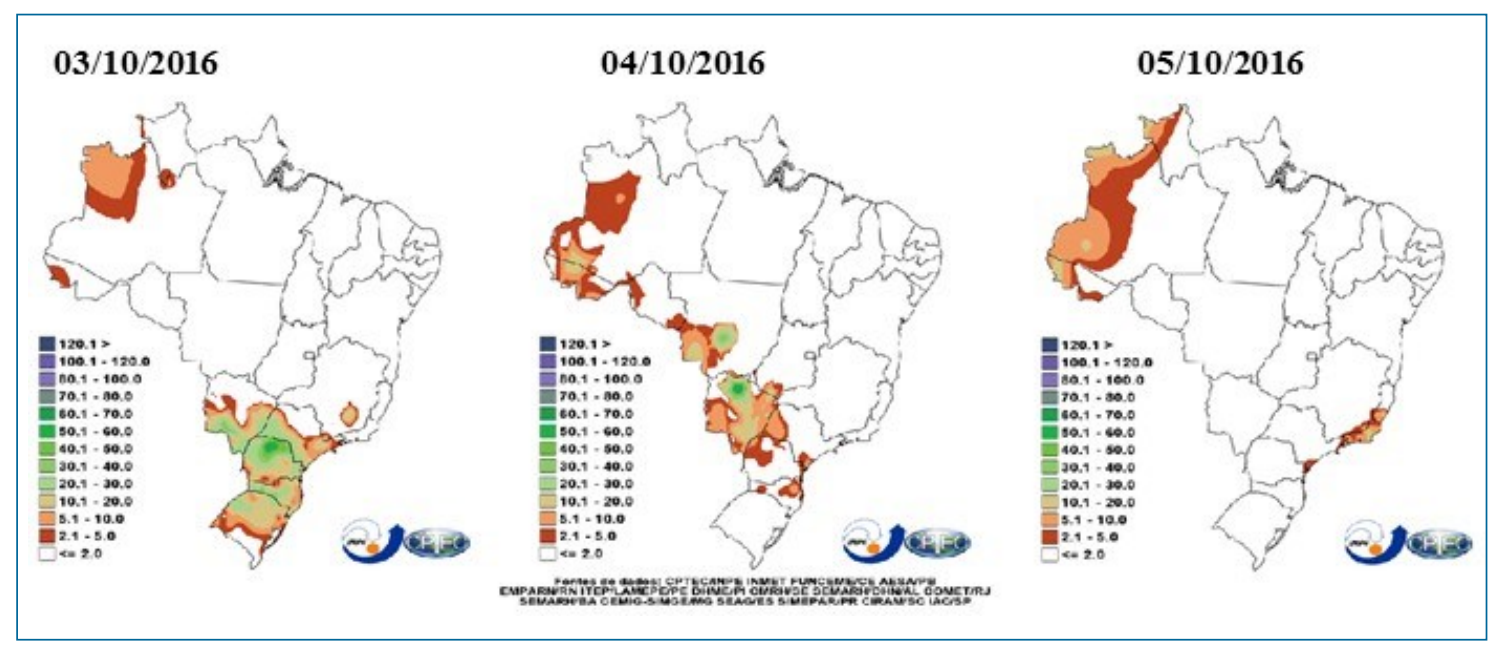

Figure 12 - Precipitation data for the days 3, 4, and 5 of October 2015

Source: Adaptated from (CPTEC/INPE, 2015) 


\subsubsection{Physical Parameters}

The mentioned legislation (CONAMA 357/2005, 396/2008, and MS 2914/2011) does not present reference values for temperature. However, temperature is important because of its impact on other properties, since it accelerates chemical reactions and reduces gas solubility. According to the Brazilian Code for Mineral Waters established in 1945, Caldas da Imperatriz is a hyper-thermal fountain, that is, the temperature of the water leaving the soil is higher than $38^{\circ} \mathrm{C}$. In this experiment, in situ measurements revealed that water temperature was 39.5 degrees Celsius for all samples.

Color and turbidity are organoleptic parameters. Users prefer water that has no color or turbidity, because the presence of color can lead to psychological aversion, and association with wastewater, for example. Color in water can be caused by dissolved and suspended materials. In this study, water analyses revealed zero Hazen units of color, meaning that there were no substances in suspension.

Turbidity showed zero UNT for all sample sites, which is in compliance with the 2914/11 legislation of the Ministry of Health that establishes the maximum of 5 UNTs. The analyzed samples did not present suspended solids, which reduce their transparency.

According to the organoleptic parameter, water must be colorless, odorless, and tasteless, thus providing confidence to the user.

\subsubsection{Chemical Parameters}

Table 1 below shows the values obtained for the $\mathrm{pH}, \mathrm{DO}$, nitrite, nitrate, sulfate, and BOD in the analyses of the collected samples.

Table 1 - Chemical parameter results for DO, $\mathrm{pH}$, Nitrite, Nitrate, Sulfate, and BOD

\begin{tabular}{c|c|c|c|c|c|c}
\hline $\begin{array}{c}\text { Collection } \\
\text { date }\end{array}$ & $\begin{array}{c}\text { DO } \\
\mathrm{pmm} / \mathrm{m}\end{array}$ & $\mathrm{pH}$ & $\begin{array}{c}\text { Nitrite } \\
\mathrm{mg} / \mathrm{L}\end{array}$ & $\begin{array}{c}\text { Nitrate } \\
\mathrm{mg} / \mathrm{L}\end{array}$ & $\begin{array}{c}\text { Sulfate } \\
\mathrm{mg} / \mathrm{L}\end{array}$ & $\begin{array}{c}\text { BOD } \\
\mathrm{mg} / \mathrm{L}\end{array}$ \\
\hline Standard & $6^{(2)}$ & $6 \mathrm{a} 9^{(2)}$ & $1^{(1)}$ & $10^{(1)}$ & $250^{(1)}$ & $<3^{(2)}$ \\
\hline $02 / 03 / 2015$ & 7.7 & 6.36 & 2 & 3.0 & 0 & 50 \\
\hline $06 / 04 / 2015$ & 7.0 & 6.22 & 0 & 2.0 & 0 & 60 \\
\hline $04 / 05 / 2015$ & 7.3 & 7.24 & 0 & 1.0 & 0 & 25 \\
\hline $12 / 08 / 2015$ & 6.0 & 7.13 & 1.5 & 3.3 & 0.5 & 10 \\
\hline $08 / 09 / 2015$ & 6.9 & 7.17 & 1 & 1.3 & 0.3 & 25 \\
\hline $05 / 10 / 2015$ & 6.3 & 7.14 & 1 & 2.0 & 0.3 & 40 \\
\hline
\end{tabular}

(1) Ordinance 2914/2011 of the Ministry of Health; (2) CONAMA Resolution 357/2005.

According to CONAMA resolution 357/2005, DO concentration should be higher than $6 \mathrm{mg} / \mathrm{L}$. As can be seen in Table 1 , the values obtained in the analyses ranged from $7.7-6.0 \mathrm{mg} / \mathrm{L}$; thus, meeting the standards established by the resolution.

The values obtained in the $\mathrm{pH}$ analyses ranged from 6.22 to 7.24 . Therefore, they were in compliance with the parameters of the CONAMA resolution 357/2005, which determines that water should have a pH value between 6.0 and 9.0. The level of $\mathrm{pH}$ represents the most important single chemical parameter of hydrogen ion concentration, providing useful indication of water acidity, neutrality, or alkalinity. The analyzed samples showed little variation regarding neutrality conditions. Alterations in $\mathrm{pH}$ can lead to several health disorders. Water with $\mathrm{pH}$ levels outside the parameters may cause irritation to eyes, skin, and mucous membranes.

According to the ordinance 2914/2011 of the Ministry of Health, the maximum value for nitrite concentration (NO2-) is 1 $\mathrm{mg} / \mathrm{L}$. Analysis of the water samples collected on March 2 and August 12, 2015 (Table 1), revealed that nitrite concentration was 2 and $1.5 \mathrm{mg} / \mathrm{L}$, respectively. The measured values did not meet the parameter determined by law. The reason was probably due to a rainfall volume of 2.1-5 millimeters that occurred on February 28, as shown in Figure 7. Nitrite values found on August 12, 2015 cannot be related to precipitation, since no rainfall occurred during the collection period, as it can be seen in Figure 7.

The results of the remaining analyses met the maximum amount of nitride established by the ordinance 2914/2011 of the Ministry of Health. Figure 8 shows that, on April 6, there was a rainfall volume of 5.1-10 millimeters; even so, the result of the analysis was zero mg/L. Differently from what happened on March 2 and August 12, 2015, in this case, rainwater did not have time to infiltrate into the groundwater table. Therefore, the values obtained for the water analysis met the requirements of the CONAMA resolution 357/2005 and ordinance 2914/2011 of the Ministry of Health. Since we are dealing with an outcrop sheet, a 48-hour period was sufficient for nitrite present in the soil to be drawn into the source. Because nitrite is an anion, and the $\mathrm{pH}$ range found in these soils predominate negative charges, nitrite ions can be easily leached through the soil to groundwater and nearby aquifers.

The maximum chemical parameter value for nitrate (NO3-) is $10 \mathrm{mg} / \mathrm{L}$, according to the ordinance $2914 / 2011$ of the Ministry of Health. As it can be seen in Table 1, the values obtained in the analyses were $3.3-1.0 \mathrm{mg} / \mathrm{L}$. Therefore, all samples 
met the requirements of the mentioned legislation.

Nitrate values found in the samples collected on March 2 and August 12, 2015 may have been solubilized by water and infiltrated into the groundwater during the rainy period that preceded the sample collections or may be the product of nitrate oxidation. Even so, all values obtained were within the parameters established by the legislation. Nonetheless, the values decrease with each analysis performed. The cause of this decline may be due to the decrease in rainfall volume, which are soluble in water due to the negative charge of nitrite ions.

The results corroborate the inspections during field visits, since no plantations were observed in the surroundings of the fountain, except for domestic crops of fruit species. Therefore, water contamination by agricultural fertilizers was discarded.

The maximum chemical parameter value for sulfate $\left(\mathrm{SO}_{42}{ }^{-}\right)$is $250 \mathrm{mg} / \mathrm{L}$, according to the ordinance $2914 / 2011$ of the Ministry of Health. Results for the first three analyses indicated zero $\mathrm{mg} / \mathrm{L}$. However, the value was different from zero for the subsequent analyses, as shown in Table 1. Sulphate is one of the most abundant ions in nature. In natural waters, sulfate is formed by the dissolution of soils and rocks and by sulfite oxidation (CETESB, 2009).

During the degradation of organic matter, bacteria make use of oxygen in their respiratory processes, and may cause a concentration reduction in the environment. Therefore, the BOD chemical parameter underwent a variation in the analyses for the three samples collected.

The CONAMA resolution 357/2005 determines that the BOD should not exceed $3 \mathrm{mg} / \mathrm{L}$. The CONAMA resolution $396 / 2008$ does not take BOD as a parameter of water quality. In this study, BOD values ranged from $10-60 \mathrm{mg} / \mathrm{L}$, that is, they were above the parameter determined by the legislation. None of the BOD results obtained for the samples collected met the requirements of the CONAMA resolution 357/2005.

The BOD may indicate the presence of organic matter from sanitary sewage. However, this assumption is not valid, since all analyses had negative results for fecal coliforms. Furthermore, field inspections found no residences near the fountain, and the wastewater generated from the hotel was properly collected and treated (CETESB, 2009).

\subsubsection{Biological Parameters}

The presence of fecal coliform in aquatic environments may indicate that the water has been contaminated, with the potential risk of the presence of pathogenic organisms (SIQUEIRA et al., 2010). The results for coliforms were negative for all samples in the presumptive test. According to the ordinance 2914/2011 of the Ministry of Health, confirmatory tests for thermotolerant coliforms are not required when the results in the presumptive test are negative. In this study, there were no pathogenicity indicators $(<1.1 \mathrm{MPN} / 100 \mathrm{~mL})$.

\section{Conclusions}

All physical parameters regarding color, turbidity, and temperature met the requirements of CONAMA resolutions 396/2008 and 357/2005, and ordinance 2914/11 of the Ministry of Health. The most restrictive value was sought when the two legislations had different values.

The chemical parameters for $\mathrm{pH}$, nitrate, sulfate, and DO met all the requirements of CONAMA resolutions 357/2005 and 396/2008, and ordinance 2914/2011 of the Ministry of Health. The chemical parameters for nitrite and BOD had changes in the results throughout the research period. Nitrite had non-standard values in the first sample collection, but complied with the requirements in the other collections, whereas BOD had significant non-standard values and did not comply with the legislation, due to the massive rainfall during the sample collection period, which may have influenced the results, as mentioned earlier.

The tests for total coliforms and thermotolerant coliforms presented negative results for the biological parameter in all samples analyzed. There was no possibility of water contamination by the coliform group bacteria, given that the fountain was inside an environmental preservation area. The wastewater treatment by the nearby hotels should continue and be monitored frequently.

According to the ordinance 2914/11 of the Ministry of Health, to determine water quality, sample collections must be evenly distributed along the whole year round, encompassing the different seasons.

Nonetheless, this study showed that physicochemical and biological analyses of color, turbidity, temperature, $\mathrm{pH}$, nitrate, nitrate, sulfate, DO, BOD, and coliforms, which are quality parameters, in addition to pollution indicators, can provide reliable results related to water quality of the Companhia Hidromineral Caldas da Imperatriz. However, weather-climatic conditions have great influence on the results, since the analyzed water fountain is close to the surface.

\section{Acknowledgements}

Thanks to Companhia Hidromineral Caldas da Imperatriz for authorizing the study and collaborating with its development. 


\section{Referências}

AMERICAN PUBLIC HEALTH ASSOCIATION. Standard methods for the examination of water and wastewater. 20 ed. Washington:APHA, 1998.

The Human Right to Water and Sanitation; United Nations Department of Economic and Social Affairs. United Nations 2013 [cited 2016 mar 07]. Available from: http://www.un.org/waterforlifedecade/human_right_to_water.shtml

Lei N. 7.841 de 8 de agosto de 1945. Código de Águas Minerais. Diário Oficial da União (Brasília). 1945 Ago 09.

Conselho Nacional Do Meio Ambiente. Resolução № 357 de 17 de março de 2005. Dispõe sobre a classificação dos corpos de água e diretrizes ambientais para o seu enquadramento, bem como estabelece as condições e padrões de lançamento de efluentes, e dá outras providências. Brasília (Brasil): CONAMA; 1945.

Conselho Nacional Do Meio Ambiente. Resolução no 396 de 03 de abril de 2008. Dispõe sobre a classificação e diretrizes ambientais para o enquadramento das águas subterrâneas e dá outras providências. Brasília (Brasil): CONAMA; 2008.

MINISTÉRIO DA SAÚDE; Conselho Nacional de Saúde. Portaria N² 2914 de 12 de dezembro de 2011. Dispõe sobre os procedimentos de controle e de vigilância da qualidade da água para consumo humano e seu padrão de potabilidade. Brasília (Brasil): Ministério da Saúde; 2011.

Companhia Ambiental do Estado de São Paulo. Qualidade Das Águas Interiores No Estado de São Paulo 2009 [cited 2016 mar 10]. Available from: http://www.cetesb.sp.gov.br/userfiles/file/agua/aguas-superficiais/variaveis.pdf

CUNHA LF, SHIRAIWA S. Aplicação do Método Eletromagnético Indutivo na Investigação da Pluma de Contaminação da Água Subterrânea por Resíduos de Cromo de Curtema. Revista Brasileira de Geofísica. 2011;29:128134.

MINISTÉRIO DE MINAS E ENERGIA; Departamento Nacional de Produção Mineral. Sumário Mineral 2015 [cited 2016 jan 11]. Available from: http://www.dnpm.gov.br/dnpm/sumarios/sumario-mineral-2015

MINISTÉRIO DA SAÚDE; Fundação Nacional de Saúde. Manual Prático de Análise de Água. Brasília (Brasil): Ministério da Saúde; 2013.

HIRATA R, ZOBY JLG, OLIVEIRA FR. Ground Water: Strategic or Emergency Reserve. California Department of Water Resources. 2016:119-136.

INSTITUTO BRASILEIRO DE GEOGRAFIA E ESTATÍSTICA [Internet]. Brasília: Ministério do Planejamento, Orçamento e Gestão (BR) [cited 2016 mar 05]. Pesquisa Nacional de Saneamento Básico 2008. Available from: http:// www.ibge.gov.br/home/estatistica/populacao/condicaodeida/pnsb2008/PNSB_2008.pdf

INSTITUTO BRASILEIRO DE GEOGRAFIA E ESTATÍSTICA [Internet]. Brasília: Ministério do Planejamento, Orçamento e Gestão (BR) [cited 2015 abr 15]. Cidades: Santa Catarina. Available from: http://www.cidades.ibge.gov. br/xtras/perfil.php?lang=\&codmun=421570\&search=santa-catarina $\mid$ santo-amaro-da-imperatriz

Instituto Nacional de Pesquisas Espaciais. INPE/CPTEC [cited 2015 abr 15]. Available from: http://www.cptec.inpe.br/ JOHNSON H, SOUTH N, WALTERS R. The commodification and exploitation of fresh water: Property, human rights and green criminology. International Journal of Law, Crime and Justice. 2016;44:146-162.

LAURENTI, A. Qualidade da Água I. 1. ed. Florianópolis: Imprensa Universitária, 1997.

LAZZERINI FT. Fontes Hidrominerais do Brasil: Componentes Biologicamente ativos (BAC) Naturais [thesis]. Rio Claro: Instituto de Geociência e Ciências Exatas/UNESP; 2013. 388 p. 
LOBLER C A, ERTEL T, MARTELLI G V, SILVA JLS. Pontos Potenciais de Contaminação e Vulnerabilidade Natural das Águas Subterrâneas do Município de Restinga Seca - RS. Revista Brasileira de Geografia Física. 2013;06(03):500509.

MADEIRA F. Avaliação dos efeitos da imersão diária em água termomineral de Caldas da Imperatriz-SC na Inflamação periférica em camundongos [dissertation]. Santa Catarina: PPGCS/UNISUL; 2016. 119 p.

MARQUES ED, SILVA-FILHO EV, SOUZA GVC, GOMES OVO. Seasonal variations of water quality in a highly populated drainage basin, SE Brazil: water chemistry assessment and geochemical modeling approaches.

Environmental Earth Sciences. 2016;75:1498-1516.

MENEZES JPC, BERTOSSI APA, SANTOS, A. R.; NEVES, M. A. Correlação Entre Uso da Terra e Qualidade da Água Subterrânea. Engenharia Sanitária Ambiental. 2014;19(2):173-186.

MERTEN GH, MINELLA JP. Qualidade da Água em Bacias Hidrográficas Rurais: Um Desafio Atual Para a Sobrevivência Futura. Agroecologia e desenvolvimento rural sustentável. 2002;3(4):34-38.

Notícias Do Dia [cited 2017 mar 15]. Available from: https://ndonline.com.br/florianopolis/noticias/tradicionalfontanario-de-agua-termal-em-santo-amaro-da-imperatriz-passa-a-cobrar-pela-agua-distri

QUINTELA MM. Banhos que curam: Práticas termais em Portugal e no Brasil. Etnográfica. 2003;7(1):171-185.

REBOUÇAS AC. Água e desenvolvimento rural. Estudos Avançados. 2001;15(43):327-344.

ROSADO TL, MONÇÃO OP, GONTIJO I, PIRES FR. Efeito da Cobertura Vegetal Nos Atributos Físicos de um Latossolo Amarelo Cultivado com Banana. Enciclopédia Biosfera. 2012;8(15):721-728.

ROYAL MRL, MARTÍNEZ-SANTOS P. Intensive Groundwater Use: Silent Revolution and Potential Source of Social Conflicts. Journal of Water Resources Planning and Management. 2005;131(5):337-341.

SILVA RCA, ARAUJO TM. Qualidade da água do Manancial Subterrâneo em Áreas Urbanas de Feira de Santana (BA). Ciência \& Saúde Coletiva. 2003;8(4):1019-1028.

SIQUEIRA LP, SHINOHARA NKS, LIMA RMT, PAIVA JE, LIMA FILHO JL, CARVALHO IT. Avaliação Microbiológica da Água de Consumo Empregada em Unidades de Alimentação. Ciência \& Saúde Coletiva. 2010;15(1):63-66.

SEWELL, G. H. Administração e Controle da Qualidade Ambiental. São Paulo: Gen, 2011.

Secretaria De Turismo E Cultura. Turismo termal [cited 2016 out 30]. Available from: http://www.santoamaro.tur.br/ turismo-termal

UNESCO. International Hydrological Programme. World water resources at the beginning of the 21st century. Cambridge University Press, Cambridge. 1998.

VAITSMAN DS, VAITSMAN MS. Água Mineral. Rio de Janeiro: Interciência, 2005.

VERONE BP. Análise da Influência da Precipitação Pluviométrica e do Uso do Solo Sobre a Qualidade da Água em Microbacias Hidrográfica no Bordeste Paraense, Amazônia Oriental [dissertação]. Vitória: Engenharia Ambiental/ UFES; 2011.173 p.

Leopoldo Duarte Pereira

Universidade do Sul de Santa Catarina, Palhoça, Brasil

Author Participation: field, performed the experiments, data analysis, and in the interpretation of the results

Email: leopoldoduartepereira@gmail.com 


\section{Marcielly Melo Freitas}

Universidade do Sul de Santa Catarina, Palhoça, Brasil

Email:marciellyfreitas@hotmail.com

Author Participation: field, performed the experiments, data analysis, and in the interpretation of the results.

\section{Aline Ferreira Ali de Ávila}

Universidade do Sul de Santa Catarina, Palhoça, Brasil

Email:alli.avilla@gmail.com

Author Participation: guided the experiments, interpretation of the results and revised final version of the work.

\section{José Gabriel da Silva}

Universidade do Sul de Santa Catarina, Palhoça, Brasil

Email:jose.gabriel@unisul.br

Author Participation: discussions of results and revised final version of the work.

\section{Rachel Faverzani Magnago}

Universidade do Sul de Santa Catarina, Palhoça, Brasil

Email:rachel.magnago@unisul.br

Author Participation: participated in the field, guided the experiments, data analysis, interpretation of the results and revised final version of the work. 